\title{
PENGARUH PERKEMBANGAN TEKNOLOGI INFORMASI DAN LAYANAN TELEKOMUNIKASI TERHADAP PENINGKATAN PENDAPATAN MASYARAKAT INDONESIA
}

\author{
Ariyani Wardhana \\ Jurusan Sistem Informasi, Fakultas Ilmu Komputer, Binus University \\ Jl. KH. Syahdan No. 9, Palmerah, Jakarta Barat 11480. \\ ratnavati_ariyani_wardhana@binus.ac.id
}

\begin{abstract}
Information technology development grows faster every year. This phenomena makes opportunity for new businesses and business expansions in various industrial segments, especially for small and medium industries. Information technology is a part of support value in Porter's value chain to optimalize industry performance. Application development, capacity amount, and various facilities in mobile phone access such as voice call, SMS, MMS, GPRS, 3G, 4G, and Vas add value to support primary business activities in each sector to earn more income. Income raise in many industries will bring impacts in national income and prosperity.
\end{abstract}

Keywords: information technology, value chain, income

\begin{abstract}
ABSTRAK
Perkembangan teknologi informasi dan layanan telekomunikasi semakin pesat dari tahun ketahun. Hal ini membuka peluang usaha baru dan perluasan usaha di berbagai sektor terutama untuk usaha kecil dan menengah. Teknologi informasi adalah bagian dari nilai dukungan dalam rantai nilai Porter untuk mengoptimalkan kinerja industri. Perkembangan aplikasi, jumlah kapasitas dan fasilitas layanan yang semakin beragam mulai panggilan telpon, sms, mms, gprs, 3G, 4 G, VAS meningkatkan nilai dukungan terhadap aktivitas utama bisnis di sektor masing-masing sehingga memungkinkan perusahaan untuk memaksimalkan margin laba ataupun memperbesar pendapatan. Peningkatan pendapatan perusahaan akan membawa dampak pada perekonomian nasional terutama dalam pengentasan kemiskinan dan pemerataan kesejahteraan di kota dan di desa.
\end{abstract}

Kata kunci: teknologi informasi, rantai nilai, pendapatan 


\section{PENDAHULUAN}

Dunia bisnis di Indonesia sudah banyak mengalami perubahan seiring dengan pesatnya perkembangan teknologi. Mesin-mesin canggih yang dapat memangkas waktu kerja, mengoptimalkan kapasitas produksi, menurunkan biaya variable, serta peran sistem informasi yang mampu menganalisa dan menghasilkan laporan yang lebih variatif sehingga memudahkan para eksekutif untuk menentukan langkah bagi perusahaannya.

Seiring dengan peningkatan dan penyebaran pengunaan sistem informasi dalam dunia bisnis, maka persaingan dunia bisnis juga semakin ketat dan perubahannya sangat cepat. Perubahan persaingan ini telah memberikan kesempatan baru bagi sebagian orang untuk meningkatkan usaha dan pendapatannya selain dampak buruk bagi yang tidak mampu bersaing. Kesempatan ini telah meningkatkan pendapatan perorangan maupun industri. Hal ini berdampak pada semakin marak dan banyak industri kecil menengah yang berkembang dalam era informasi ini.

Perkembangan teknologi komunikasi sebagai bagian dari perkembangan teknologi komputer telah memberikan warna tersendiri bagi strategi pemasaran dan cara mendapatkan informasi dari pihak luar perusahaan hingga cara mengkomunikasikan target dan misi dalam internal perusahaan.

Tabel 1

Jumlah Perusahaan Menurut Sub Sektor Tahun 2001 - 2009

\begin{tabular}{|c|c|c|c|c|c|c|c|c|c|}
\hline Sektor & 2001 & 2002 & 2003 & 2004 & 2005 & 2006 & 2007 & 2008 & 2009 e) \\
\hline Makanan dan minuman & 4559 & 4551 & 4414 & 4639 & 4722 & 6615 & 6341 & 6063 & 5819 \\
\hline Tembakau & 810 & 814 & 788 & 810 & 858 & 1286 & 1208 & 1131 & 1657 \\
\hline Tekstil & 1901 & 1892 & 1847 & 1892 & 1934 & 2809 & 2820 & 2355 & 1949 \\
\hline Pakaian jadi & 2123 & 2028 & 1883 & 1908 & 1922 & 3256 & 2917 & 2655 & 2045 \\
\hline Kulit dan barang dari kulit & 564 & 533 & 512 & 492 & 491 & 813 & 764 & 685 & 619 \\
\hline $\begin{array}{l}\text { Kayu, barang dari kayu, dan } \\
\text { anyaman }\end{array}$ & 1668 & 1629 & 1450 & 1411 & 1325 & 1782 & 1648 & 1435 & 1566 \\
\hline $\begin{array}{l}\text { Kertas dan barang dari } \\
\text { kertas }\end{array}$ & 388 & 340 & 375 & 394 & 413 & 526 & 553 & 477 & 535 \\
\hline $\begin{array}{l}\text { Penerbitan, percetakan, dan } \\
\text { reproduksi }\end{array}$ & 537 & 593 & 545 & 535 & 545 & 897 & 789 & 748 & 607 \\
\hline $\begin{array}{l}\text { Batu bara, minyak dan gas } \\
\text { bumi, dan bahan bakar } \\
\text { nuklir }\end{array}$ & 48 & 40 & 54 & 48 & 52 & 73 & 96 & 84 & 44 \\
\hline $\begin{array}{l}\text { Kimia dan barang-barang } \\
\text { dari bahan kimia }\end{array}$ & 1089 & 1014 & 1003 & 1020 & 1011 & 1179 & 1151 & 1082 & 886 \\
\hline $\begin{array}{l}\text { Karet dan barang-barang } \\
\text { dari plastik }\end{array}$ & 1416 & 1466 & 1422 & 1487 & 1477 & 1847 & 1774 & 1715 & 2199 \\
\hline Barang galian bukan logam & 1657 & 1612 & 1518 & 1507 & 1523 & 2047 & 1916 & 1783 & 1373 \\
\hline Logam dasar & 239 & 223 & 209 & 230 & 211 & 276 & 260 & 237 & 218 \\
\hline $\begin{array}{l}\text { Barang-barang dari logam } \\
\text { dan peralatannya }\end{array}$ & 906 & 930 & 896 & 880 & 859 & 1020 & 981 & 902 & 600 \\
\hline Mesin dan perlengkapannya & 529 & 474 & 390 & 408 & 410 & 477 & 436 & 435 & 332 \\
\hline $\begin{array}{l}\text { Peralatan kantor, akuntansi, } \\
\text { dan pengolahan data }\end{array}$ & 9 & 9 & 8 & 7 & 7 & 10 & 10 & 9 & 34 \\
\hline $\begin{array}{l}\text { Mesin listrik lainnya dan } \\
\text { perlengkapannya }\end{array}$ & 235 & 244 & 247 & 249 & 252 & 279 & 285 & 271 & 261 \\
\hline Radio, televisi, dan perlatan & 141 & 167 & 206 & 219 & 191 & 227 & 227 & 205 & 320 \\
\hline
\end{tabular}




\begin{tabular}{|c|c|c|c|c|c|c|c|c|c|}
\hline komunikasi & & & & & & & & & \\
\hline $\begin{array}{l}\text { Peralatan kedokteran, alat } \\
\text { ukur, navigasi, optik, dan } \\
\text { jam }\end{array}$ & 69 & 52 & 49 & 47 & 47 & 61 & 70 & 70 & 69 \\
\hline Kendaraan bermotor & 216 & 270 & 256 & 261 & 262 & 336 & 302 & 305 & 271 \\
\hline Alat angkutan lainnya & 354 & 329 & 334 & 323 & 297 & 380 & 380 & 333 & 475 \\
\hline $\begin{array}{l}\text { Furniture dan industri } \\
\text { pengolahan lainnya }\end{array}$ & 1914 & 1898 & 1855 & 1856 & 1865 & 3135 & 2914 & 2569 & 3106 \\
\hline Daur ulang & 24 & 38 & 63 & 62 & 55 & 137 & 156 & 145 & 92 \\
\hline & 21396 & 21146 & 20324 & 20685 & 20729 & 29468 & 27998 & 25694 & 25077 \\
\hline
\end{tabular}

Sumber: Badan Pusat Statistik Republik Indonesia (Statistics Indonesia)

Hal ini sesuai dengan value chain 'rantai nilai' Michael Porter yang menyebutkan bahwa aktivitas bisnis dibagi menjadi dua, yaitu primary activity 'aktivitas utama' dan support activity 'aktivitas pendukung'. Adapun perkembangan teknologi yang merupakan bagian dari support activity pada persaingan di era globalisasi ini sangat berpengaruh bagi primary activity untuk meningkatkan pendapatan dan laba usaha atau margin seperti Gambar 1 dibawah ini.

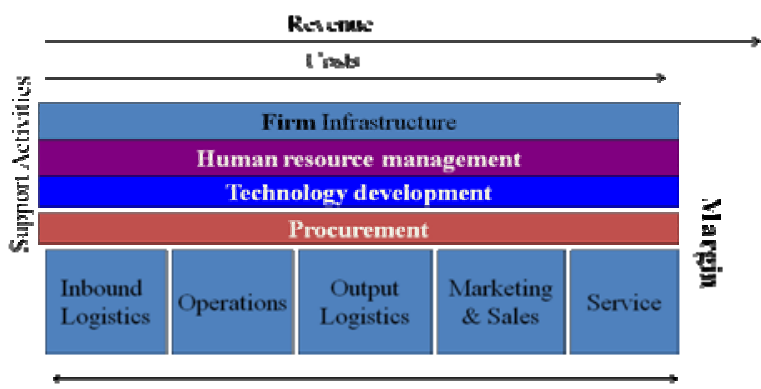

Primears . Kctn iliox

Gambar 1. Value chain Michael Porter.

Meningkatnya penggunaan teknologi tidak hanya dikalangan pebisnis, tetapi juga konsumen. Teknologi modem yang makin baik dan jaringan komunikasi yang makin luas serta perkembangan teknologi mobile phone hingga smart phone membuat konsumen semakin mudah mencari informasi dan melakukan transaksi untuk pemenuhan kebutuhannya. Pertambahan dan perluasan penggunaan teknologi komunikasi ini juga dipicu dengan menurunnya harga layanan komunikasi dan penurunan harga peralatan komunikasinya. Oleh karena itu transaksi bisnis juga mulai bergeser kearah brick and mortar ataupun click and mortar.

Konsumsi jasa telekomunikasi yang terus meningkat di kalangan masyarakat Indonesia dari segala lapisan, membuka peluang usaha baru sehingga konsumsi dana perusahaan untuk strategi pemasaranpun bergeser dan persaingan dilakukan tidak hanya dengan strategi pemasaran konvensional. Bahkan beberapa perusahaan seperti Domino Pizza, Holycow, Sour Sally, J.Co Donuts and Coffee, dan lain sebagainya menggunakan perkembangan teknologi komunikasi dan aplikasi sistem informasi sebagai strategi andalan untuk memasarkan produk dan jasanya serta memperoleh laba.

Arah perkembangan bisnis telekomunikasi di indonesia juga telah bergeser dari layanan suara saja (1980-an) hingga layanan aplikasi (2010). Selain itu akses informasi di dunia maya lewat ponsel sejak 2004 mulai berkembang dari yang pada awalnya hanya sebagai alat komunikasi suara dan text (SMS). Pengguna ponsel dengan kemampuan GPRS, 3G, 4G, atau VAS hingga tahun 2010 diperkirakan mencapai 80 juta pengguna. Menurut survey Siemens mobile lifestyle sekitar $60 \%$ usia 
muda (15-29 tahun) menggunakan ponsel mereka sepanjang hari. Perkembangan sektor telekomunikasi di Indonesia pada tahun 2009 mengalami peningkatan (Tabel 2), hal ini dikarenakan naiknya permintaan pasar akan jasa komunikasi dan informasi. Sedangkan untuk sektor penerbitan, percetakan, dan reproduksi media rekaman mengalami penurunan (Tabel 3). Nilai tambah sub sektor telekomunikasi pada tahun 2009 mengalami peningkatan yang cukup signifikan (47.33\%) (Tabel 4), sedangkan sektor penerbitan, percetakan, dan reproduksi media rekaman perkembangannya lebih kecil (34.75\%) (Tabel 5).

Tabel 2

Jumlah Perusahaan Menurut SubSektor Radio, Televisi, dan Peralatan komunikasi yang Terus Meningkat

\begin{tabular}{lcccccccccc}
\hline Sektor & $\mathbf{2 0 0 1}$ & $\mathbf{2 0 0 2}$ & $\mathbf{2 0 0 3}$ & $\mathbf{2 0 0 4}$ & $\mathbf{2 0 0 5}$ & $\mathbf{2 0 0 6}$ & $\mathbf{2 0 0 7}$ & $\mathbf{2 0 0 8}$ & $\mathbf{2 0 0 9}$ e) \\
\hline $\begin{array}{l}\text { Radio, televisi, dan perlatan } \\
\text { komunikasi }\end{array}$ & 141 & 167 & 206 & 219 & 191 & 227 & 227 & 205 & 320 \\
\hline e: angka perkiraan & & & & & & & & & \\
\hline
\end{tabular}

Sumber: Jumlah Perusahaan Menurut SubSektor, 2001-2009 (Badan Pusat Statistik RI).

Tabel 3

Jumlah Perusahaan Menurut SubSektor Penerbitan, Percetakan, dan Reproduksi Media Rekaman

\begin{tabular}{lccccccccc}
\hline Sektor & $\mathbf{2 0 0 1}$ & $\mathbf{2 0 0 2}$ & $\mathbf{2 0 0 3}$ & $\mathbf{2 0 0 4}$ & $\mathbf{2 0 0 5}$ & $\mathbf{2 0 0 6}$ & $\mathbf{2 0 0 7}$ & $\mathbf{2 0 0 8}$ & $\mathbf{2 0 0 9}$ e) \\
\hline $\begin{array}{l}\text { Penerbitan, percetakan, dan } \\
\text { reproduksi }\end{array}$ & 537 & 593 & 545 & 535 & 545 & 897 & 789 & 748 & 607 \\
\hline e: angka perkiraan & & & & & & & & & \\
\hline
\end{tabular}

Sumber: Jumlah Perusahaan Menurut SubSektor, 2001-2009 (Badan Pusat Statistik RI)

Tabel 4

Nilai Tambah Menurut Subsektor Radio, Televisi, dan Peralatan Komunikasi

\begin{tabular}{|c|c|c|c|c|c|c|c|c|c|}
\hline & 2001 & 2002 & 2003 & 2004 & 2005 & 2006 & 2007 & 2008 & 2009 e) \\
\hline $\begin{array}{l}\text { Radio, televisi, dan } \\
\text { peralatan } \\
\text { komunikasi }\end{array}$ & 9,000 & 15,086 & 15,934 & 18,015 & 15,506 & 18,364 & 18,331 & 14,622 & 21543 \\
\hline
\end{tabular}

Sumber: Nilai Tambah Menurut Subsektor , 2001-2009 (milyar rupiah) (Badan Pusat Statistik RI).

Tabel 5

Nilai Tambah Menurut Subsektor Penerbitan, Percetakan, dan Reproduksi Media Rekaman

\begin{tabular}{l|c|c|c|c|c|cccc}
\hline & $\mathbf{2 0 0 1}$ & $\mathbf{2 0 0 2}$ & $\mathbf{2 0 0 3}$ & $\mathbf{2 0 0 4}$ & $\mathbf{2 0 0 5}$ & $\mathbf{2 0 0 6}$ & $\mathbf{2 0 0 7}$ & $\mathbf{2 0 0 8}$ & $\mathbf{2 0 0 9}$ e) \\
\hline $\begin{array}{l}\text { Penerbitan, percetakan, dan } \\
\text { reproduksi }\end{array}$ & 1,110 & 3,102 & 3,465 & 5,116 & 5,010 & 6,499 & 7,517 & 6,313 & 8507 \\
\hline e: angka perkiraan & & & & & & & & & \\
\hline
\end{tabular}

Sumber: Nilai Tambah Menurut Subsektor, 2001-2009 (milyar rupiah) (Badan Pusat Statistik RI).“ 
Penurunan jumlah penduduk miskin di Indonesia hingga tahun 2009 terjadi baik di kota maupun desa (Tabel 6). Hal ini menandakan tingkat kesejahteraan masyarakat Indonesia secara keseluruhan lebih baik dari tahun ketahun.

Tabel 6

Tingkat Kemiskinan di Indonesia Periode 2007 - 2009

\begin{tabular}{|c|c|c|}
\hline \multicolumn{3}{|c|}{ Tingkat kemiskinan di Indonesia } \\
\hline tahun & kota & desa \\
\hline 2007 & 13559.30 & 23609.00 \\
\hline 2008 & 12768.50 & 22194.80 \\
\hline 2009 & 11910.50 & 20619.44 \\
\hline
\end{tabular}

Sumber: Badan Pusat Statistik RI

\section{METODE}

Metode yang digunakan dalam penelitian ini adalah analisis korelasi dengan koefisien korelasi bivariate/product moment pearson untuk mengukur keeratan hubungan diantrara hasil-hasil pengamatan dari populasi yang mempunyai 2 varian (bivariate).

\section{HASIL DAN PEMBAHASAN} ditolak.

Berdasarkan probabilitas, jika probabilitas $>0.05$ H0 diterima, jika probabiltas $<0.05$ H0

Besaran korelasi berkisar antara 0 (tidak ada hubungan sama sekali) hingga 1 (korelasi sempurna). Tanda negatif pada output menunjukkan adanya arah hubungan berlawanan, sedangkan tanda positif menunjukkan arah hubungan yang sama.

H0 (a): tidak ada hubungan antara perkembangan sektor Radio, Televisi, dan Peralatan komunikasi dengan tingkat kemiskinan di kota

H1 (a): ada hubungan antara perkembangan sektor Radio, Televisi, dan Peralatan komunikasi dengan tingkat kemiskinan di kota

H0 (b): tidak ada hubungan antara perkembangan sektor Radio, Televisi, dan Peralatan komunikasi dengan tingkat kemiskinan di desa

H1 (b): ada hubungan antara perkembangan sektor Radio, Televisi, dan Peralatan komunikasi dengan tingkat kemiskinan di desa

H0 (c): tidak ada hubungan antara perkembangan sektor penerbitan, percetakan, dan reproduksi media rekaman dengan tingkat kemiskinan di kota

H1 (c): ada hubungan antara perkembangan sektor penerbitan, percetakan, dan reproduksi media rekaman dengan tingkat kemiskinan di kota

H0 (d): tidak ada hubungan antara perkembangan sektor penerbitan, percetakan, dan reproduksi media rekaman dengan tingkat kemiskinan di desa

H1 (d): ada hubungan antara perkembangan sektor penerbitan, percetakan, dan reproduksi media rekaman dengan tingkat kemiskinan di desa

H0 (e): tidak ada hubungan antara perkembangan sektor Radio, Televisi, dan Peralatan komunikasi dengan nilai Tambah Menurut Subsektor Radio, Televisi, dan Peralatan komunikasi 
H1 (e): ada hubungan antara perkembangan sektor Radio, Televisi, dan Peralatan komunikasi dengan nilai Tambah Menurut Subsektor Radio, Televisi, dan Peralatan komunikasi

H0 (f): tidak ada hubungan antara perkembangan sektor penerbitan, percetakan, dan reproduksi media rekaman dengan Nilai Tambah Menurut Subsektor Penerbitan, Percetakan, dan Reproduksi media rekaman

H1 (f): ada hubungan antara perkembangan sektor penerbitan, percetakan, dan reproduksi media rekaman dengan Nilai Tambah Menurut Subsektor Penerbitan, Percetakan, dan Reproduksi media rekaman

H0 (g): tidak ada hubungan antara perkembangan sektor penerbitan, percetakan, dan reproduksi media rekaman dengan perkembangan sektor penerbitan, percetakan, dan reproduksi media rekaman

H1 (g): ada hubungan antara perkembangan sektor penerbitan, percetakan, dan reproduksi media rekaman dengan perkembangan sektor penerbitan, percetakan, dan reproduksi media rekaman

H0 (h): tidak ada hubungan antara jumlah kemiskinan di kota dengan jumlah kemiskinan di desa

H1 (h): ada hubungan antara jumlah kemiskinan di kota dengan jumlah kemiskinan di desa

H0 (i): tidak ada hubungan antara nilai tambah sektor komunikasi dengan nilai tambah sektor penerbitan, percetakan dan reproduksi media rekaman

H1 (i): ada hubungan antara nilai tambah sektor komunikasi dengan nilai tambah sektor penerbitan,percetakan dan reproduksi media rekaman

Tabel 7 di bawah ini merangkum data korelasi perkembangan industri dan nilai tambah industri.

Tabel 7.

Korelasi Perkembangan Industri Komunikasi, Perkembangan Industri Penerbitan, Percetakan dan Reproduksi Media Rekaman, Nilai Tambah Industri Komunikasi, Nilai Tambah Industri Percetakan dan Reproduksi Media Rekaman, Kemiskinan di Kota, Kemiskinan di Desa

\begin{tabular}{|c|r|r|r|r|r|r|}
\hline & kota & desa & NTIK & JIK & JIP & NTIP \\
\hline kota Pearson Cor & 1 & $1.000^{*}$ & -.484 & -.777 & .970 & -.471 \\
Sig. (2-tailed) &. & .005 & .678 & .434 & .156 & .688 \\
$\mathrm{~N}$ & 3 & 3 & 3 & 3 & 3 & 3 \\
\hline desc Pearson Cor & $1.000^{*}$ & 1 & -.491 & -.782 & .972 & -.478 \\
Sig. (2-tailed) & .005 &. & .673 & .429 & .151 & .683 \\
$\mathrm{~N}$ & 3 & 3 & 3 & 3 & 3 & 3 \\
\hline NTIK Pearson Cor & -.484 & -.491 & 1 & .927 & -.682 & $1.000^{\star}$ \\
Sig. (2-tailed) & .678 & .673 &. & .244 & .522 & .009 \\
$\mathrm{~N}$ & 3 & 3 & 3 & 3 & 3 & 3 \\
\hline JIK Pearson Cor & -.777 & -.782 & .927 & 1 & -.906 & .922 \\
Sig. (2-tailed) & .434 & .429 & .244 &. & .278 & .254 \\
$\mathrm{~N}$ & 3 & 3 & 3 & 3 & 3 & 3 \\
\hline JIP Pearson Corl & .970 & .972 & -.682 & -.906 & 1 & -.671 \\
Sig. (2-tailed) & .156 & .151 & .522 & .278 &. & .532 \\
$\mathrm{~N}$ & 3 & 3 & 3 & 3 & 3 & 3 \\
\hline NTIF Pearson Corn & -.471 & -.478 & $1.000^{*}$ & .922 & -.671 & 1 \\
Sig. (2-tailed) & .688 & .683 & .009 & .254 & .532 &. \\
$\mathrm{~N}$ & 3 & 3 & 3 & 3 & 3 & 3 \\
\hline **Correlation is significant at the 0.01 level (2-tailed).
\end{tabular}

Dari hasil olah data diatas disimpulkan bahwa terima H0 (a,b,c,d,e,f,g) karena probabilitasnya di atas 0.05. hipotesis H0 (h,i) disimpulkan tolak H0 karena probabilitasnya lebih kecil sama dengan 0.05. Hal ini berarti terdapat hubungan antara jumlah kemiskinan di kota terhadap jumlah kemiskinan di desa. Secara logika dapat dipahami karena jika jumlah kemiskinan di kota naik berarti sektor perekonomian tidak berjalan dengan baik, banyak pengangguran. Sektor usaha disegala bidang juga sebagian besar berpusat di kota, sehingga jika kota mengalami kemunduran akan berdampak secara tidak langsung pada perekonomian dan tingkat kemiskinan di desa. Nilai tambah sektor komunikasi 
berhubungan dengan nilai tambah sektor penerbitan, percetakan, dan reproduksi media rekaman. Sedangkan untuk perkembangan sektor komunikasi dan percetakan serta nilai tambah masing-masing sektor tidak ada hubungan signifikan pada jumlah kemiskinan di kota maupun di desa. Hal ini juga dapat dipahami karena jumlah kemiskinan tidak hanya ditentukan semata-mata oleh ke dua sektor bisnis tersebut, masih banyak elemen social, ekonomi, dan politik yang mempunyai pengaruh terhadap jumlah kemiskinan di kota dan di desa.

Dari hasil analisa korelasi tersebut juga didapat kesimpulan bahwa: (1) Perkembangan sektor industri komunikasi akan berpengaruh kuat kepada menurunnya jumlah kemiskinan di kota dan jumlah kemiskinan di desa; (2) Perkembangan sektor industri penerbitan, percetakan dan reproduksi media rekaman berpengaruh kuat pada meningkatnya jumlah kemiskinan di kota dan jumlah kemiskinan di desa; (3) Nilai tambah sektor komunikasi dan sektor penerbitan, percetakan dan reproduksi media rekaman tidak berpengaruh pada penurunan jumlah kemiskinan baik dikota maupun di desa; (4) Perkembangan sektor industri komunikasi berpengaruh pada penurunan sektor penerbitan, percetakan, dan reproduksi media rekaman. Hal ini dapat dipahami karena dengan meningkatkan penggunaan teknologi, gaya hidup dan persaingan bisnis menjadi berubah. Perubahan ini tentunya berdampak pada sektor bisnis yang masih konvensional (non paperless). Penerbitan yang dulu menggunakan kertas dapat dijadikan digital seperti e-book, website, blog, dan sebagainya. Penerbitan dengan cara digital akan menurunkan daya jual dari sektor penerbitan biasa, sehingga jumlah industri yang akan menggelutinya juga akan menurun.

\section{PENUTUP}

Dari hasil uji hipotesis dapat simpulkan bahwa: (1) Perkembangan teknologi informasi dan perkembangan layanan telekomunikasi tidak berkorelasi secara signifikan dengan jumlah kemiskinan Indonesia baik di kota maupun di desa; (2) Naiknya nilai tambah sektor komunikasi (radio, televisi, peralatan komunikasi serta perlengkapannya) dan layanan telekomunikasi memiliki pengaruh yang signifikan terhadap naiknya nilai tambah sektor penerbitan, percetakan, dan reproduksi media rekaman; (3) Pertambahan/penurunan jumlah kemiskinan di kota berpengaruh pada pertambahan/ penurunan jumlah kemiskinan di desa secara searah; (4) Perkembangan teknologi informasi dan layanan komunikasi membuka peluang untuk industri di kelas usaha kecil dan menengah di berbagai bidang. Hal ini mampu membuka peluang untuk peningkatan pendapatan dan penurunan kemiskinan serta pemerataan kesejahteraan yang lebih baik.

\section{DAFTAR PUSTAKA}

Badan Pusat Statistik RI. (2009). Jumlah Perusahaan Menurut SubSektor 2001-2009. Diakses dari http://www.bps.go.id/tab_sub/view.php?tabel=1\&daftar=1\&id_subyek=09\&notab=2.

Badan Pusat Statistik RI. (2009). Nilai Tambah Menurut Subsektor, 2001-2009 (Milyar rupiah). Diakses http://www.bps.go.id/tab_sub/view.php?tabel=1\&daftar=1\&id_subyek=09\&notab=3. 